WIDER Working Paper 2017/31

\title{
Trade in services
}

Opening markets to create opportunities

Bernard Hoekman*

February 2017 
Abstract: This paper reviews the role of services in development and growth, the potential role of trade in services as a driver of the productivity performance of sectors that use services as inputs, and the links between services policies and domestic trade costs. Barriers to trade in services have direct as well as indirect effects on cross-border trade and investment, but research suggests that the extent to which countries will benefit from open services regimes and regional integration of services markets depends on complementary efforts to improve economic governance and regulatory regimes.

Keywords: services, productivity, growth, regional integration, Africa JEL classification: F13, F15, F23, O24

Acknowledgements: I am grateful to Richard Newfarmer and other participants in the June 2016 Helsinki conference for helpful comments and to Matteo Fiorini for his help in putting together the results reported in Section 5.

* European University Institute and Centre for Economic Policy Research, Bernard.Hoekman@EUI.eu.

This study has been prepared within the UNU-WIDER project on 'Industries without smokestacks', which is part of a larger research project on 'Jobs, poverty and structural change in Africa'.

Copyright (C) UNU-WIDER 2017

Information and requests: publications@wider.unu.edu

ISSN 1798-7237 ISBN 978-92-9256-255-7

Typescript prepared by Joseph Laredo.

The United Nations University World Institute for Development Economics Research provides economic analysis and policy advice with the aim of promoting sustainable and equitable development. The Institute began operations in 1985 in Helsinki, Finland, as the first research and training centre of the United Nations University. Today it is a unique blend of think tank, research institute, and UN agency — providing a range of services from policy advice to governments as well as freely available original research.

The Institute is funded through income from an endowment fund with additional contributions to its work programme from Denmark, Finland, Sweden, and the United Kingdom.

Katajanokanlaituri 6 B, 00160 Helsinki, Finland

The views expressed in this paper are those of the author(s), and do not necessarily reflect the views of the Institute or the United Nations University, nor the programme/project donors. 
African trade is heavily concentrated in agricultural and natural resource-based commodities and the agricultural sector continues to be a major source of employment and economic activityespecially when indirect ancillary linkages are taken into account. Although trade volumes have risen since the 1990s, and exports of some industrial and processed products have been increasing, intra-regional trade remains well below potential, and the challenge of diversification continues to prevail. There are encouraging prospects for accelerating trade growth as a result of policy reforms, ranging from trade facilitation efforts to the high-level political ambition to achieve regional integration objectives - e.g. through a continental free trade agreement. Much depends on the willingness and ability of African leaders to deliver on their stated objectives. A premise of this paper is that a precondition for leveraging trade opportunities is a substantial reduction in trading and transaction costs for African firms, and that this must go beyond the current focus on actions to facilitate trade and focus more on improving the performance of a variety of services, including transport, logistics, and related services.

ACET (2014) emphasizes that agriculture must play a central role in boosting growth and structural transformation, and identifies a number of specific areas that offer substantial opportunity, including: (i) processing and adding value to traditional export crops; (ii) scaling up exports of fruits and horticulture by upgrading supply chains, investing in processing plants, and developing agribusiness services; and (iii) reducing agricultural imports from the rest of the world by building regional value chains - e.g. producing poultry meat and associated inputs such as soybean cake in different sub-regions of Africa. The same is true of manufacturing activities and associated urban development, which have been the subject of significant attention in the literature (e.g. Newman et al. 2016; Rodrik 2014). Making progress along these lines and enhancing the share of value added created in Africa will require improving the availability of and access to a range of ancillary services, and more generally increasing the productivity of firms supplying services.

McMillan and Rodrik (2011) have noted that in Africa the process of structural transformation in which workers move out of agriculture/rural locations into other economic sectors/urban centres has not been accompanied by the shift observed in East Asia (and more generally among current OECD member countries in the course of their economic history), which is characterized by a shift from low- to higher-productivity activities, with manufacturing absorbing a large proportion of the workers who move out of agriculture, and an overall rise in economy-wide productivity performance. The pattern that is observed instead in many African countries is one of a shift of people from rural areas into the urban informal sector or into low-productivity service activities (retail, personal services, etc.), with little in the way of an expansion of the manufacturing sector.

Why this is the case is an active subject of research and debate. Whatever one's views about the inherent value of a rising share of manufacturing in total employment, it should be recognized that modern manufacturing involves many service activities. Much of manufacturing is undergoing a process of 'servicification', involving a focus on the provision (sale) of the services that are generated by products as opposed to simply the fabrication and sale of tangible goods. Distinguishing between the manufacturing and services sectors is rapidly becoming less meaningful. What matters from the perspective of structural transformation is not so much shifting resources out of rural agriculture into urban manufacturing assembly plants as moving resources into activities that generate high(er) value added and increase aggregate productivity. Such activities will often revolve around or be classified as services, whether they take place in industry or as stand-alone services. 
A key factor then is to understand why there is limited investment in economic activities that generate higher productivity per worker than in agricultural production or associated rural activities. Many services are relatively skill-intensive and are associated with higher productivity, but some relatively low-skilled service activities also offer opportunities for real wages that are higher than in agriculture-e.g. those related to the tourism industry. One reason for the observed pattern of (lack of) transformation in Africa may be that the overall 'services environment' precludes investment in higher-value activities-whether these are in agriculture/processing or manufacturing or services-related. This is generally captured in the literature through an analysis of the investment climate and business environment as determinants of investment incentives, but it can also be viewed through the lens of whether firms (potential investors) have access to the services they need in order to be able to produce competitive products.

Services are increasingly tradable as a result of technological advances, investments in 'backbone' infrastructure and connectivity, and policy reforms that increase the contestability of services markets, including the liberalization of FDI and gradual progress in regional integration within Africa. These developments permit increases in direct exports of services by allowing the sale/provision of services over ICT networks, and suppliers/customers to physically move to satisfy the proximity constraint that still prevails in allowing services transactions to occur. While developments in areas such as software and apps, business process outsourcing, and the like attract much attention, services play an important role in determining industry-level competitiveness and the ability of entrepreneurs to participate in value chains and to add value to products.

Reducing trade costs in Africa is in (large) part a challenge of increasing productivity in a variety of service activities - most obviously in the areas of transport and logistics, less obviously in areas such as communications and financial services. The level of trade costs associated with moving goods and services (including service providers) from one country to another is largely a function of the costs of the services that are needed to enable cross-border movement. But trade costs are also a function of the quality and costs of a variety of intermediate services that are inputs into the production of trade goods and services. The lower the productivity of firms providing intermediate services, the more disadvantaged the sectors that source from them.

Trade in services - broadly defined to include cross-border exchange through telecommunications channels, the temporary movement of service suppliers or consumers, and foreign direct investment (FDI) (establishment in a host country by foreign affiliates that produce/sell services) - is therefore one potential channel for productivity growth. Trade in services allows specialization according to comparative advantage. In that regard there is no difference between goods and services. What is different is that trade in services requires a movement of providers, whether legal entities (firms) or natural persons (service suppliers), which implies that a (much) broader range of policy instruments and underlying public policy concerns arise than in the case of trade in goods. Another difference, at least in degree, is that many services are critical inputs for a large number of industries, and thus that imports of services may be a particularly important channel for productivity growth.

This paper reviews some of the literature on trade in services, with an emphasis on recent analyses of services trade policies and their effects. The plan of the paper is as follows. Section 2 briefly reviews the role of services in development and growth, the potential role of trade in services, and recent evidence of the magnitude of services trade costs. Section 3 discusses the indirect effect of services trade and investment policies on the productivity of downstream firms and presents some research indicating that market opening can bring significant gains in productivity. Section 4 turns to the direct effects of trade barriers on services trade and the potential for services trade liberalization to expand trade in Africa, drawing on recent case study evidence. Section 5 argues that the extent to which countries will benefit from open services regimes depends on the quality 
of economic governance. This appears to be particularly significant for services trade, in part reflecting the role that FDI plays as a channel for foreign suppliers to provide services, which suggests that policy needs to go beyond a focus on services trade barriers to span regulatory regimes and institutions. Section 6 discusses what could be done through regional integration to reduce services trade barriers, the state of play in this regard in Africa, and what research on services trade policy suggests should be on the agenda looking forward. Section 7 concludes.

\section{Services, trade, and structural transformation}

The share of services in total output and employment for the world as a whole has been increasing over time as countries become richer. This is nothing new (see, for example, Kravis et al. 1983), but for any level of economic development the role of services in the economy is today more important than in the past as a result of advances in information and communication technologies and transport. Efficient services are critical for economic development because they are determinants of the productivity of capital and labour (think of the role that financial services intermediaries play in providing funds to firms that have been generated by households seeking to invest their savings and the role that health and education services play in enhancing the skills and quality of life of workers). Services are also the backbone of connectivity- 'facilitating' the physical movement of goods and people (transport services) and the exchange of knowledge and information (communications services). Many business and professional services such as accounting, legal services, and management consulting are important inputs into the production process of firms. Thus, the performance of the services sector matters for economic growth and the overall productivity of the economy as a whole.

Given the prima facie importance of services for economic development and growth, it is surprising that there is relatively little research on how services matter and the types of policies that will support the emergence of dynamic and efficient services sectors. Standard textbook treatments postulate that growth in total income (GDP) depends on the endowments of basic factors of production (capital and labour) and the rate at which their productivity increases over time. What is neglected is the role that services play in determining both the initial stock of capital and labour in an economy at any given point in time and the rate of productivity growth, as well as more general technological progress. ${ }^{1}$

An increasing share of services in GDP and employment is part and parcel of economic development and thus a key feature of structural transformation. From a growth perspective there is nothing inherently negative about shifting resources into services, or in countries pursuing a development strategy (growth path) that involves rapid expansion in service activities and less in the way of manufacturing production than was the case in the past for countries that were successful in becoming high-income economies. Successful (desirable) structural transformation is not conditional on achieving significant growth in the share of manufacturing assembly operations; it is conditional on expanding the share of economic activities that generate higher average real wages (higher productivity). Such activities need not involve a preponderance of the types of industries and production that drove development in the past, because technologies today (e.g. regional or global value chains) allow firms to specialize and outsource services that used to be

${ }^{1}$ Further discussion of these different linkages can be found in Schettkat and Yocarini (2006), Eichengreen and Gupta (2009), and Berlingieri (2014). 
provided within the firm. Most of the value added embodied in products-whether goods or services-reflects services inputs, whether provided through the market or within the firm.

Services lend themselves just as much to productivity growth as does manufactured goods production. Structural transformation is in part an inter-sectoral dynamic-from low-productivity agriculture and informal services to higher-productivity work in the formal sectors (both goods and services)_but just as important are shifts within sectors, including increasing demand for intermediate services (Berlingieri 2014). Within services, resource allocation shifts are a driver of productivity growth in the same way as in goods-producing sectors. Young (2014) finds that average productivity growth in services is similar to that in other sectors. The presumption that most services are unproductive, best illustrated in Baumol's (2012) celebrated view of the inherent 'cost disease' that accompanies a rising share of services in GDP, is incorrect. Growth in the production (and consumption) of services as countries grow richer is not just a function of final demand patterns and income elasticities (Herrendorf et al. 2013).

Historically many services could be characterized as non-tradable as a result of their non-storable and intangible nature. An implication was that international trade in many services required the cross-border movement of providers - in turn involving the movement of capital and labour. The need for such factor movement has been declining as the result of technical change that allows services to be digitized and provided cross-border through ICT networks, as well as of improvements in transportation, connectivity, and information networks that allow firms to both identify market opportunities and exploit them. However, trade costs for services remain much higher than trade costs for goods, and the rate of decline in such costs has been less than is often realized. Miroudot and Shepherd (2016) report estimates of the ad valorem tariff equivalent of international trade costs for different services sectors. As can be seen, costs differ substantially across sectors, transport having the lowest trade costs on average and construction the highest. The obvious implication of high services trade costs is that the volume of trade in services is reduced. A less obvious implication is that the ability of firms to exploit their competitive advantages on world markets is compromised (Storeygard 2016).

Firm-level surveys undertaken by the World Bank across a large number of countries indicate that average export performance is stronger for large firms than for SMEs, with exports accounting for an average of 29 per cent of sales of the former, but only 16 per cent of the latter (Hoekman and Shepherd 2015a). This result is well known: there is extensive evidence that large companies generally export much more than small ones and account for the lion's share of exports of any country. One reason for this is economies of scale, which reduce unit trade costs. SMEs produce and trade lower volumes, implying higher unit trade costs, given that many trade costs have a significant fixed component. This is one reason why trade facilitation and the recent WTO Agreement on Trade Facilitation is important for SMEs. But the types of customs clearance costs that are the focus of trade facilitation are just one component of overall trade costs for firms. Services costs - such as the costs and quality of transport and logistics - are another important component. The quality of logistics services in each country, as measured by the World Bank Logistics Performance Indicators, accounts for more than 12 per cent of the observed variation in the percentage of sales directly exported by the SMEs that are included in the World Bank Enterprise Survey dataset, compared with only 2 per cent for large firms (Hoekman and Shepherd 2015a).

One consequence of high trade costs is that many services tend to be traded indirectly. Recent initiatives such as the effort by the OECD and W'TO to measure trade in value added (TiVA) have educated many in the trade policy community about some basic features of economic structures and international exchange that have long been understood by specialists and that are part and parcel of the national accounts and input-output tables: services account for a significant share of 
the value added of all sectors in the economy. As this value added is embedded in traded goods, services play a much larger role in international exchange than is measured by a nation's balance of payments (BOP). At least 50 per cent of global trade on a value added basis comprises services: the sum of the value of services output that is traded directly and is captured in BOP statistics (some 20 to 25 per cent of total exports), plus the value of services that is embedded in trade goods (another 25 to 35 per cent). Case study evidence suggests that at the level of the enterprise the services content of output (the share of services in total costs or total value added) is high in both developing and developed countries (Low 2013). However, the services intensity of production is higher on average in high-income countries, reflecting a steady increase over time in the use of (reliance on) purchases by firms in all sectors of outsourced business and professional services.

The fact that high services trade costs mean that imports of services often entail inward FDI has implications for growth and employment. As long as greater foreign factor participation is associated with increased competition, FDI inflows will expand the scale of activity, and hence increase the scope for generating growth-enhancing effects. Conversely, a larger scale achieved merely by eliminating domestic barriers to entry and attracting domestic resources from other sectors could also generate larger endogenous growth as resources are allocated to more productive resources. Even without scale effects and even if services sectors do not possess endogenous growth attributes, inward FDI following services sector liberalization can have positive effects on growth by bringing in new technology. Moreover, because services are produced locally, greater foreign competition through FDI will generally have less of an effect in forcing a reallocation of employment across sectors than in the case of liberalization of trade in goods (Konan and Maskus 2006). There is substantial empirical evidence that FDI has positive effects on productivity by inducing greater competition and providing access to higher-quality, more varied, and cheaper services (Francois and Hoekman 2010).

An increasing number of studies and reports have analysed the role of services trade and related policies from an economic development perspective (see for instance Mattoo and Payton 2007; Cali et al. 2008; World Bank 2010; Saez et al. 2015; Dihel and Goswami 2016; Balchin et al. 2016), complementing studies of developed economies (e.g. Breinlich and Criscuolo 2011; Wagner 2012). This literature has generated findings that apply to both developing and developed country contexts, e.g. that firm heterogeneity plays an important role in shaping patterns of services trade, much as is the case for trade in goods, as do barriers to trade and regulatory regimes for product markets. What follows is a discussion of one important determinant of services performance and thus economy-wide productivity-policies towards trade and investment in services-focusing on the role that services play as inputs into production of both goods (manufactured) and other services.

\section{Services trade policies and economic performance}

Services trade policies matter for many dimensions of economic performance. For example, services trade policy has been shown to matter for product differentiation and diversification. Building a gravity framework for more than 100 countries, Nordås (2011) finds that price-reducing liberalization in business services is associated with greater product differentiation, particularly in the motor vehicle industry. On the basis of these findings, she argues that services market opening should be considered as an element of strategies for industrial upgrading in developing countries. Miroudot and Shepherd (2015) find that a 10 per cent increase in the level of services trade restrictiveness is associated with an increase in trade costs of 2.7-3.1 per cent, using trade costs data compiled by Arvis et al. (2015), the biggest effects being in postal services and telecommunications. Borchert et al. (2015) note that many landlocked African countries restrict 
trade in services that could have a significant effect on overall trade performance; for example, air transport policies tend to be significantly more restrictive than in other countries, reducing connectivity with the rest of the world. The consequence is more concentrated market structures and less access to transport services. Even moderate liberalization of air transportation services by landlocked Sub-Saharan countries could generate a 20 per cent increase in the number of flights.

This type of research has become possible as a result of new datasets. Research on the effects of services trade policies has traditionally been impeded by data limitations. Policy information is often patchy at best, time series data on key policy variables generally not being available on a cross-country, comparable basis, and such information frequently not existing at country level either. This situation has changed recently with the publication of a new dataset by the World Bank that characterizes the restrictiveness of policies towards services trade and investment (Borchert et al. 2014). The World Bank database covers five services sectors and three modes of supply: cross-border trade, commercial presence (FDI), and temporary movement of service suppliers. Not all of these are relevant for all sectors, and in some cases policies affecting a mode of supply apply to many or all sectors. The Services Trade Restrictiveness Index (STRI) is a numerical summary of applied services policies believed to affect trade flows. The more restrictive a country is towards trade and investment in services, the higher its STRI.

Figure 1 summarizes the data, which are available for only one year at present. The reported STRIs present an overall indicator, in the sense of a summary number that covers all sectors and modes. The average STRI for the Sub-Saharan countries included in the database is 32. The general picture that emerges is that African countries are relatively liberal when it comes to Mode 1 (cross-border supply of services), but have higher levels of trade restrictiveness in place for Mode 3 (sales through establishment by foreign affiliates, i.e. FDI) (not plotted). However, policy measures vary considerably by sector and country. Although Africa is relatively liberal (open) on the basis of the STRI measures, it should be kept in mind that the STRI covers only one dimension of services policies - the extent to which policy discriminates against foreign providers. It does not capture the types of trade costs associated with corruption and inefficient border clearance for services suppliers or the performance of services sectors such as transport and logistics. As discussed below, the available evidence suggests that the quality of economic governance broadly defined plays an important role in determining the extent to which African firms and households benefit from reductions in services trade restrictions.

Of particular interest from the perspective of this paper is the effect of policies that limit the ability of (raise the costs for) foreign firms to provide services in a market. Empirical research on this question is of relatively recent vintage due to the absence of data on prevailing policies. In an early paper, Mattoo et al. (2006) use a cross-section regression framework to show that countries with open financial and telecommunications sectors display a GDP growth rate about 1.5 percentage point higher than other countries. Eschenbach and Hoekman (2006) find that liberalization and adoption of good regulatory practices for financial, telecommunications, energy, and transport services were statistically significant explanatory variables for the economic performance of a sample of 20 transition economies during the 1990-2004 period. 


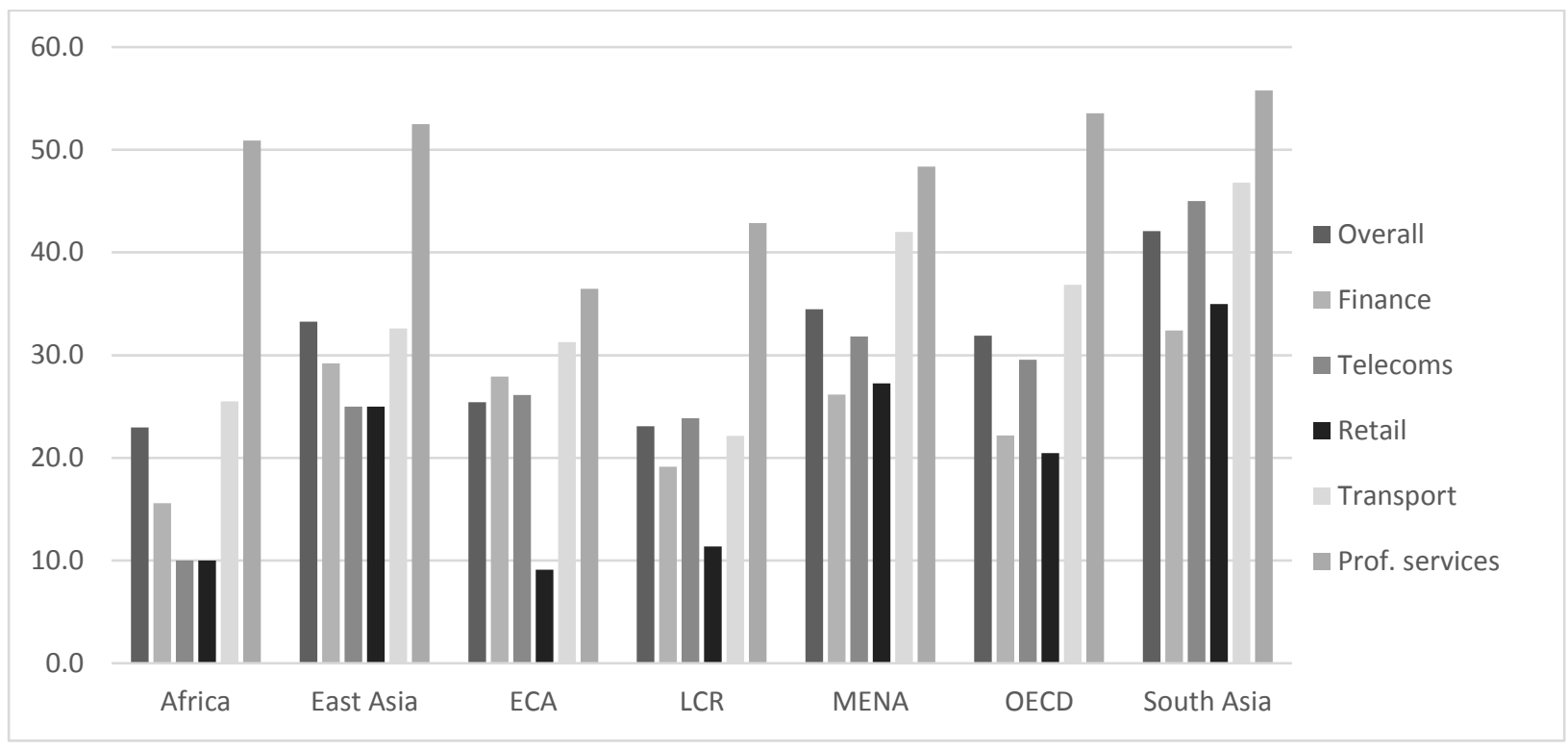

Source: World Bank Services Trade Restrictions Database.

A positive association between policy reforms in services and inward FDI in services, and between total factor productivity (TFP) growth in the performance of downstream firms and FDI is perhaps the most robust finding to emerge from the limited empirical research on the impacts of services reforms (Francois and Hoekman 2010). FDI is a particularly important channel for the transfer of services-related know-how and technology, as foreign firms introduce new types of services that may be better suited to the needs of clients, or provide existing services at lower cost than was available before they entered the market. International trade and investment in services provides local firms and households with more choice. Greater competition in services markets and access to a broader range of differentiated services should increase the total factor productivity of firms in proportion to the intensity with which services are used. Thus, firms that are relatively intensive users (buyers) of services should benefit the most from measures that increase the availability of services in an economy.

This applies as much to lower-income countries as it does to high-income economies. Arnold et al. (2008) use data from over 1,000 firms in 10 Sub-Saharan African economies to analyse this question, and conclude that there is a statistically significant positive relationship between the observed TFP of these firms and their assessments of the performance of financial and telecommunications services industries. More recent research on individual economies that focuses on the effects of (changes in) services policies over time finds that more open services markets are associated with better productivity performance of downstream industries. This has been shown by Arnold et al. (2011) for the Czech Republic, Bas (2014) for India, and Duggan et al. (2013) for Indonesia, as well as for OECD nations (Barone and Cingano 2011; Bourlès et al. 2013).

Greater competition on services markets also matters for the productivity of (other) services sectors, as different services industries all source inputs from each other. Miroudot et al. (2012) use a gravity model setting to estimate cross-border (Mode 1 and Mode 2) trade costs in 12 services sectors for 61 countries and find that lowering services trade costs by 10 per cent is associated with a 0.5 per cent gain in services TFP. Similarly, Van der Marel (2012) shows that services trade and investment policies (notably FDI regulations) are a determinant of TFP growth in services sectors. All of this research therefore demonstrates the importance from a policy perspective of 
recognizing the 'input role' of services when it comes to efforts to improve the productivity performance of the economy.

Hoekman and Shepherd (2015b) build on these types of analysis using more recent data for a large sample of firms and developing countries. Using World Bank enterprise survey data for 58,000 firms in over 100 developing countries, they find that services sector productivity matters for the productivity of downstream firms producing goods, with services productivity mattering more for those firms that use services relatively intensively in their overall input mix, as is to be expected. The strength of the productivity linkages varies substantially across the African countries in their sample, reflecting differing intensities of use of services inputs in the production process. They also find that the relationship depends on services trade: lower barriers to services trade and investment increase the productivity performance of domestic manufacturing industries. They find that, at the average rate of services input intensity, a 10 per cent improvement in services productivity is associated with an increase in manufacturing productivity of 0.3 per cent, as well as higher exports of manufactures. While the effects are statistically significant, they are relatively small in magnitude compared with the findings in the above-mentioned country case studies, suggesting that country-specific and institutional variables may play an important intermediating role. As in the country-specific analyses briefly mentioned above, less open FDI regimes appear as the core causal channel for this link.

Hoekman and Shepherd (2015b) also use a gravity regression framework to analyse the relationship between levels of services trade policies and merchandise export performance, using the services trade restrictiveness index (STRI) compiled by Borchert et al. (2014). They find that exports of manufactured products depend in part on policies towards trade in services, and this finding holds up if one controls for the effect of other variables such as trade policy towards goods sectors. For any given country pair, on average a 2 per cent rise in the level of services trade restrictiveness is accompanied by a 1 per cent decline in the value of bilateral merchandise trade. While this type of analysis does not consider general equilibrium effects, the magnitude of the effect is substantially greater than what is obtained from estimates using firm-level data. Hoekman and Shepherd (2015b) find that policies that restrict trade in transport and retail distribution services have the largest negative impact on merchandise exports. This is intuitive, as global value chains and international trade more generally depend on access to reliable and low-cost logistics services, the quality of transport and logistics services being particularly important for higher-value products (World Bank 2014).

Results for specific countries help to provide a sense of how variation in STRIs impacts on trade performance. Focusing on the East African Community member states, which tend to be somewhat less restrictive towards trade in services than the average nation in Sub-Saharan Africa (although three of the five EAC member countries have an average services trade restriction score of 30 or higher), Hoekman and Shepherd (2015b) argue that if the EAC countries as a group were to reduce their average level of services trade restrictions to that of Ghana (the African country with the lowest services trade barriers, with an STRI of 18), their merchandise exports could increase substantially: by 13 per cent for Rwanda, and some 20 per cent for Kenya, Tanzania, and Uganda.

The upshot of the foregoing is that opening services markets can have substantial positive effects on economic activity and welfare. Computable general equilibrium models for specific African countries that incorporate estimates of the ad valorem equivalent of services trade and regulatory policies, including barriers to FDI, suggest that the opportunity cost of not focusing on the reform of services policies can be very high. Jensen et al. (2010), for example, estimate that removing restrictive services policies would increase welfare (real consumption) in Tanzania by 16 per cent 
in the long run. In the case of Kenya, Balistreri et al. (2009) conclude that welfare gains would be even greater, with real consumption increasing by some 50 per cent.

\section{The potential for services trade expansion in Africa}

The foregoing discussion has focused on the role of services as inputs into production and thus as a determinant of sectoral productivity and overall performance. Services are of course also important in themselves as sectors of activity and as potential drivers of direct exports (as opposed to their indirect role as they are embodied in traded goods). Recent technological changes are making it increasingly feasible to trade services directly, both digitally through ICT networks and the internet/cloud, and through the temporary cross-border movement of suppliers (facilitated by better information on demand, price differentials, and in some cases reductions in the cost of transportation as a result of improvements in transport infrastructure and connectivity).

The weakness of services data makes it difficult to analyse the effects of such developments on services trade. This is true even for OECD member countries, as much of what is exchanged digitally is not measured-in part because it often occurs within the boundaries of a multinational firm, and in part because it is very difficult to measure sales of services provided by suppliers that cross borders on a temporary basis. The data challenges are even greater for low-income countries. Data for many African countries are very weak; many countries do not report detailed statistics and some do not report at all. This implies that analysis of available statistics is likely to give a misleading picture of the reality 'on the ground' in Africa. On average, services account for some 50 per cent of GDP in Sub-Saharan Africa, while services trade is equal to about 10 per cent of GDP. This compares with 62 per cent and 13 per cent, respectively, for the world as a whole, suggesting that African services trade intensity is quite similar to that of the world as a whole (WDI database). Travel (including tourism) is the major export category and has been growing faster than other categories of services. That said, a number of African countries have experienced significant growth in trade in commercial services.

Case studies provide a sense of both recent developments in services trade and illustrate the potential for services trade growth for African countries. This goes much beyond the well known potential to exploit natural endowments such as good weather, beaches, and unique wildlife/nature preserves. Tourism is an important activity for many African countries in terms of contributing to employment and GDP. Tourism is dependent on many other services, ranging from telecommunications and transport to hotels and restaurants. There is substantial scope for countries to diversify beyond sun, sea, and sand tourism (beach holidays) and safaris into other types of tourism services, e.g. the medical and business tourism subsectors, and a number of countries are seeking to do so, e.g. Rwanda. A necessary condition for fully leveraging tourism potential is to have an adequate tourist-related infrastructure and a workforce that has the skills needed to interact with tourists and to provide the many 'back office' services that are inputs into the production of high-quality tourism services. Skills development, an open skies policy with liberalized bilateral air service agreements, and improved linkages between foreign travel companies and local firms are actions that are required in many African countries.

While tourism is an important sector that deserves priority attention in many countries, the potential for services trade goes far beyond tourism. Innovative firms and entrepreneurs operating in a variety of services sectors have demonstrated that Africa can compete on world markets. Equally importantly, recent research has documented that there is scope for greatly increased intraregional trade in services. Indeed, it is noteworthy how much trade in services already occurs. Based on surveys of firms and complementary innovative data collection methods in a set of 
Common Market for Eastern and Southern Africa (COMESA) countries, Dihel and Goswami (2016) conclude that more than 16 per cent of the interviewed accounting, architectural, engineering, and legal firms engage in exports, mainly to neighbouring countries. They also document substantial trade in education, health, banking, insurance, and accounting services. Importantly, too, they document that barriers affecting trade in services-for all modes of supply_lead many African service suppliers to engage in informal trade and/or significantly reduce their productivity. The case studies included in Dihel and Goswami (2016) demonstrate that entrepreneurs are able to circumvent formal barriers to cross-border trade in services and that there is substantial demand for services imports, suggesting that liberalization and services trade facilitation - to remove the need for bribes and more generally to lower transaction costs and reduce the ability of incumbent services industries (e.g. professional associations) to restrict foreign entry-have great potential to both further expand trade and increase welfare (the gains from trade).

Dihel et al. (2012) provide a case study of Kenya and discuss how new ICT technologies and improvements in ICT infrastructure and mobile internet connectivity have expanded mobile phone and internet access and supported the emergence of globally competitive services suppliers such as KenCall (business process outsourcing-BPO), Ushahidi (open source software platforms to visualize information in real time on mobile devices), and Safaricom (mobile telecoms; mobile payment services-M-Pesa). Kenyan services exports include insurance, accounting, non-bank financial, and BPO services. The regional market - the EAC - is often the largest one for smaller firms providing professional/business services. More than half of Kenyan services exporters have clients in Tanzania and/or Uganda and one-third have clients in Rwanda. Regional markets are important for exports of accounting, architecture, engineering, insurance, and legal services. In BPO, Kenyan firms export an array of services, ranging from inbound/outbound customer voice, email, and SMS support to phone-based marketing services and surveys of the customers of client firms, as well as a variety of back-office support services, including database management, storage, and back-up facilities. Kenyan firms have also become exporters of software design services, apps such as games for mobile devices, and user interface systems, as well as high-value technology services such as data recovery. While Kenya has developed a comparative advantage in such modern ICT-based and enabled services, similar trends can be observed in other African countries, including Nigeria, Mauritius, Ghana, and Senegal. Space constraints prohibit an extensive discussion of specific cases; the main point of this subsection is to illustrate that there are already substantial levels of trade in services in Africa, that there is great dynamism in services trade, and that much of this is regionally focused. ${ }^{2}$

\section{$5 \quad$ Interactions between trade policy and economic governance}

There is a big difference between the Hoekman-Shepherd estimates of the potential impacts of better services performance on merchandise exports using the WBES data and the estimated impact of services trade reforms on merchandise trade based on gravity regressions using overall country-level trade data. The latter estimates indicate that there is great potential for export growth if African firms are able to improve their access to services inputs following a reduction in their STRI, especially 'backbone services' such as transportation, retail distribution, and telecommunications. Beverelli et al. (2016) help to understand what may be driving the differences in estimated impacts of services trade restrictions. They follow an approach that has become widely

\footnotetext{
${ }^{2}$ Dihel and Goswami (2016) provide a number of excellent case studies and informed discussion of trade in services in Africa. See also Cattaneo et al. (2010), Saez et al. (2015), and Balchin et al. (2016).
} 
used in the economic literature and assume that the effect of services trade policy on downstream industries is a positive function of the intensity with which services are used as intermediate inputs. Using the World Bank STRIs, they estimate the following model:

$$
y_{i j}=\alpha+\beta \operatorname{CSTRI}_{i j}+\mu\left(\operatorname{CSTRI}_{i j} \times I C_{i}\right)+\gamma x_{i j}+\delta_{i}+\delta_{j}+\epsilon_{i j}
$$

where $y_{i j}$ is the natural logarithm of productivity in downstream sector $j$ in country $i, I C_{i}$ is a measure of economic governance (quality of the investment climate) in country $i, x_{i j}$ is a control variable (the average level of tariff protection for non-services inputs used by downstream manufacturing sector $j$ ), and $C S T R I_{i j}$ is a measure of the effective restrictiveness of services trade policy confronted by downstream sector $j$ in country $i$. This last is constructed by calculating $\sum_{s} S T R I_{i s} \times w_{i j s}$, where $S T R I_{i s}$ is the level of services trade restrictiveness for country $i$ and service sector $s$, going from 0 as complete openness to 100 as full restrictiveness, and $w_{i j s}$ are a set of weights that reflect the use of service $s$ by manufacturing sector $j$ in country $i$. The input-output ratios for the United States are used to calculate these weights. ${ }^{3}$ The same approach is used to weight the effect of import tariffs on intermediate goods used in downstream manufacturing sectors.

Using industry-level data for a sample of 57 countries they estimate the effect of services trade openness on productivity in downstream manufacturing. As in the rest of the literature, they find a positive and statistically significant impact between lower STRIs and labour productivity. However, on interacting their measure of input-use-weighted STRIs with different governance variables, they find that the effects of services trade restrictions are mediated by the quality of domestic economic governance. Thus, a similar services trade policy reform in two countries is predicted to have very different impacts on productivity of downstream sectors if the quality of institutions, as proxied by indicators such as control of corruption and rule of law, differs greatly. The positive effect of trade openness conditional on quality of economic governance does not capture differences in level of economic development. The results are insensitive to controlling for the level of per capita income.

An explanation for the effect of institutional quality may be related to the characteristics of services. Because services tend to be difficult to store or to embody in a tangible product, international provision often entails a need for providers to be physically present to deliver a service to a client. If there are barriers to the cross-border movement of suppliers, trade (provision of the service) may become impossible. However, even if a country decides to remove such barriers, trade may still not occur, or continue to be limited, if the business environment that prevails in the importing country raises operating costs significantly. If so, entry may not occur; foreign firms may decide it is not in their interest to contest the market. Thus, actions to open markets to trade in services may need to be complemented by actions to improve the investment climate and economic governance. In the absence of a level of governance that is of sufficient quality to allow firms to operate profitably, services trade liberalization may have only limited impacts. Good economic governance, measured by variables such as control of corruption, quality of regulation, and strength of rule of law, significantly increases the potential gains for an economy from services trade liberalization. This result has important implications for the design of services

\footnotetext{
${ }^{3}$ Input-output weights are given by shares of intermediate consumption. Beverelli et al. (2016) show that the estimation results are robust to the use of technical coefficients or weights derived from the Leontief inverse matrix, and that the coefficient estimates do not change substantially if the input-output ratios of China are used. For a discussion and assessments of the appropriateness of using US weights as an indicator of the technological linkages between industries see Barone and Cingano (2011).
} 
trade policy reform. In developing countries with very weak institutions the gains from services trade liberalization may be small, suggesting a need to focus attention on improving economic governance.

The relationship between institutional quality and STRIs is illustrated in Table 1 for the African countries in the sample analysed by Beverelli et al. (2016). ${ }^{4}$ Their estimated coefficient on CSTRI $i j$ $(\beta)$ and the estimated marginal effects for the interaction effect $(\mu)$ provide a qualitative assessment of the impact of higher services trade policy restrictions on downstream industries, assuming that at least some level of demand for services is observed. The marginal effect on downstream productivity of reducing barriers to services trade, accounting for cross-country heterogeneity in economic governance, $\frac{\partial y}{\partial C S T R I}=\beta+\mu \times I C_{i}$, increases with the quality of governance $(\mu<0)$ and it is positive and statistically significant at the 0.05 per cent level for 65 per cent of their sample observations (33 out of 57 countries). This result is robust to a variety of alternative approaches and instruments to account for measurement and endogeneity issues. ${ }^{5}$

To quantitatively assess how much the effect of services trade policy is influenced by economic governance quality in a country, the coefficient estimates can be used to calculate the productivity changes associated with complete removal of the restrictions to services. Since a completely unrestricted trade policy regime corresponds to an STRI of 0 , the policy change associated with a country removing all existing barriers to trade through commercial presence in services sector $s$ is given by $\left(0-S T R I_{i s}\right)$. The variation in the independent variable $C S T R I$ reflecting full liberalization of trade across the four service sectors (transport, communications, finance, and business services) is then given by:

$$
\operatorname{CSTRI}_{i j}=\sum_{s}\left(0-S T R I_{i s}\right) \times w_{i j s}
$$

The associated change in productivity (expressed in levels) implied by the estimated coefficients $(\beta$ and $\mu$ ) can then be computed as follows:

$$
\% \Delta Y_{i j}=100 \times\left(\beta+\mu \times I C_{i}\right) \times \Delta C S T R I_{i j}
$$

The productivity effect of the services trade policy of a country is a function of services input intensities at the downstream sector level and two country-level variables. The first is the policy change required to reach complete openness (STRI=0); the second is the quality of economic governance. Results are reported in Table 1 for the African countries in their sample.

In Table 1, 'Impact' refers to the estimated percentage change in sectoral labour productivity of removing all barriers to FDI in financial, transport, communications, and business services, as measured by the World Bank's STRI for Mode 3. This impact is reported for the largest manufacturing sector in each country-results for other sectors are available on request. The column 'Impact current institutions' is simply the estimated impact, while the figures in the column labelled 'High inst. (Africa)' measure the effect on labour productivity under a counterfactual scenario where the governance variable (rule of law, regulatory quality, control of corruption, respectively, in panels $\mathrm{A}, \mathrm{B}$, and $\mathrm{C}$ ) is set at the level of the African country with the best

\footnotetext{
${ }^{4}$ Data availability constraints severely limit the number of African countries that could be included in their analysis.

${ }^{5}$ Robustness checks in Beverelli et al. (2016) include instrumentation and random assignment of the policy component $\left(S T R I_{i s}\right)$ of the composite restrictiveness index, estimation with alternative input-output weights and alternative productivity measures, and variations in country and industry coverage.
} 
performance on each respective variable in our sample- the country ranked ' 1 ' in column 6. Columns 5 and 6 report the ranking of countries in terms of the average level of their STRI and different governance indicators (the more restrictive are services policies and the weaker the governance performance, the higher the number).

Table 1: Impact of removing Mode 3 barriers to labour productivity in largest manufacturing sector (\% change)

\begin{tabular}{|c|c|c|c|c|c|}
\hline & Sector & Impact current inst. & $\begin{array}{l}\text { High inst. } \\
\text { (Africa) }\end{array}$ & $\begin{array}{l}\text { STRI } \\
\text { rank }\end{array}$ & $\begin{array}{l}\text { Institutional } \\
\text { quality rank }\end{array}$ \\
\hline \multicolumn{6}{|c|}{ Governance indicator: rule of law } \\
\hline Botswana & Furniture/n.e.c. & 28.2 & 34.0 & 6 & 2 \\
\hline Burundi & Food/Bev. & -6.2 & 27.6 & 2 & 8 \\
\hline Ethiopia & Food/Bev. & 7.7 & 97.2 & 8 & 7 \\
\hline Malawi & Food/Bev. & 8.8 & 26.4 & 4 & 4 \\
\hline Mauritius & Textiles/App. & 18.3 & 18.3 & 1 & 1 \\
\hline South Africa & Food/Bev. & 27.1 & 54.7 & 7 & 3 \\
\hline Tanzania & Food/Bev. & 9.44 & 41.2 & 5 & 6 \\
\hline \multicolumn{6}{|c|}{ Governance indicator: regulatory quality } \\
\hline Botswana & Furniture/n.e.c. & 24.9 & 26.7 & 6 & 3 \\
\hline Burundi & Food/Bev. & -7.6 & 21.6 & 2 & 8 \\
\hline Ethiopia & Food/Bev. & -7.6 & 76.3 & 8 & 7 \\
\hline Malawi & Food/Bev. & 4.8 & 20.7 & 4 & 6 \\
\hline Mauritius & Textiles/App. & 14.2 & 14.4 & 1 & 2 \\
\hline South Africa & Food/Bev. & 43.0 & 43.0 & 7 & $\overline{1}$ \\
\hline Tanzania & Food/Bev. & 9.37 & 32.4 & 5 & 5 \\
\hline \multicolumn{6}{|c|}{ Governance indicator: control of corruption } \\
\hline Botswana & Furniture/n.e.c. & 34.3 & 34.3 & 6 & 1 \\
\hline Burundi & Food/Bev. & -1.6 & 27.8 & 2 & 8 \\
\hline Ethiopia & Food/Bev. & 20.1 & 98.1 & 8 & 7 \\
\hline Malawi & Food/Bev. & 6.4 & 26.6 & 4 & 6 \\
\hline Mauritius & Textiles/App. & 14.2 & 18.5 & 1 & 2 \\
\hline South Africa & Food/Bev. & 34.7 & 55.2 & 7 & 3 \\
\hline Tanzania & Food/Bev. & 14.1 & 41.6 & 5 & 5 \\
\hline
\end{tabular}

Notes: Sectors based on ISIC 2-digit classification (Food/Bev: 15+16; Textiles/Apparel: 17+18+19;

Furniture/n.e.c.: 36+37; Metals: 27; Mineral Products: 26; Chemicals: 24; Coke/Oil: 23). 'Current institutions' estimates are statistically different from zero only for Botswana, Mauritius, and South Africa.

Sources: Governance variables: World Bank Governance Indicators. Services trade policies from the World Bank Services Trade Restrictiveness Database. Labour productivity (output per worker) from UNIDO industrial statistics database. Calculated on the basis of results obtained by Beverelli et al. (2016).

Botswana and Mauritius have the best governance of this set of countries. If Botswana were to remove all Mode 3 barriers, this would generate a productivity increase in the food and beverages sector of between 24.9 and 34.3 per cent, depending on the governance indicator that is used. Similar magnitude effects are estimated for Mauritius and South Africa. However, for the other countries the impacts would be substantially smaller, despite the fact that these countries have a higher level of Mode 3 restrictions (as can be seen from their STRI ranking in column 5). If, however, the four countries with weaker governance were to improve their institutional environment to that prevailing in the best-performing Sub-Saharan African country, the positive productivity impact of services liberalization would increase by a factor of four to ten. While these estimates are only indicative, they are nonetheless informative: they illustrate that economic governance is a determinant of the magnitude of the gains from services trade liberalization.

Of course, more than an open trade regime and good economic governance will be needed to support competitive local services sectors and generate positive productivity effects. Services are relatively intensive in human capital, so it is important to have sufficiently high-quality educational services at primary, secondary, and, as it becomes appropriate, tertiary level (Saez et al. 2015) so as to ensure that workers have the skills demanded by service suppliers in areas such as ICT, finance, and business and professional services (Dihel et al. 2010). A supportive regulatory regime is also important, which, as discussed below, calls for mechanisms to allow for interactions with services 
firms and users of services (Dihel and Goswami 2016). A specific area of policy that deserves attention is the identification of whether services industries are contestable and whether specific segments of an industry are characterized by monopoly or monopsony power. For example, telecommunications sectors are often dominated by just a few suppliers that have significant ability to restrict new entry or to charge prices that are far above the cost of production. Large retailers may benefit from (and have lobbied for) policies that impede new entry into distribution and use their buying power either to reduce the prices they offer to suppliers below what would be possible if entry was allowed or to increase the prices they charge to consumers. These are empirical matters, and it is necessary to assess whether such situations arise, what the reasons for them are (are they policy-related?), and what the effects are of the exercise of market power. These are questions that are central to the application of competition law and related policy.

In practice the design of policy reforms and identification of priority areas for action must be informed by detailed analysis and consultations with stakeholders, including the business community (Hoekman and Mattoo 2013). Particularly important is to recognize the need to go beyond general findings relating to the importance of governance and to 'unpack' how different dimensions of the business environment and economic governance institutions, including sectoral policies and regulation, impact on different services industries (see the contributions in Mattoo and Payton (2007) for an example of such an analysis for Zambia). The focus of policy needs to span the various dimensions of policy that impact on the structure of services markets. While trade policy, as it pertains to both goods and services trade, should not be neglected, even in countries with weak governance, given that openness can be expected to be a force for better governance as more foreign firms enter the market, the point is that trade reforms need to be complemented by efforts to improve governance.

\section{Regional cooperation to integrate services markets}

Regional integration has long been a stated priority of many African countries, as is reflected in numerous integration efforts among subsets of African economies. An increasing recognition by African leaders that the patchwork of partially overlapping regional economic communities was sub-optimal led to a decision to gradually move towards the creation of a continent-wide free trade area (the CFTA). A feature of regional integration efforts in Africa as well as the PTAs that African countries have been negotiating or have signed with non-African nations-most notably the Economic Partnership Agreements (EPAs) with the EU-is that the focus has been on policies affecting trade in goods. This is unfortunate from the perspective of the economic relationship between access to services and measures of economic performance, including the role that services play as determinants of productivity in agriculture, mining, and manufacturing. For example, overall, across Africa, the temporary cross-border movement of service suppliers is often quite restricted and much remains to be done to address opposition by incumbent operators and sector associations to the regional liberalization of services trade. Karingi and Davis (2016) note that the average African citizen needs to obtain a visa in advance of travel for 55 per cent of the countries he or she may want to travel to. Dihel and Goswami (2016) and Dihel et al. (2012) document that there are still many regulatory barriers as well as outright discrimination against foreign professional service providers in the East and Southern African context.

Insofar as barriers to trade in services and differences in regulatory regimes pertaining to services impede services trade, regional integration efforts will have less impact on performance. Moreover, insofar as incumbent (national) services suppliers and industries oppose the opening of markets to competition from foreign firms, the exclusion of services from PTAs implies an opportunity cost, as the role that PTAs can play in changing political economy equilibria to allow the pursuit 
of efficiency-enhancing reforms is removed from the table. While services have been left to the future in the context of the EPAs with the EU, intra-Africa RECs increasingly include a focus on services. Although in many cases the extent to which PTAs liberalize trade in services and result in domestic reforms is still limited, significant progress in some dimensions has been made in some contexts. An example is the EAC Common Market Protocol, which spans trade in services and has as its objective the progressive liberalization of all four modes of supply. The Protocol imposes a standstill on new measures restricting intra-regional trade in services, and liberalization follows a so-called positive list approach (as in the WTO), where governments make commitments to liberalize specific sectors and modes of supply. The sectors chosen for initial liberalization were business and professional services, communications, distribution, education, financial services, tourism and travel-related activities, and transportation. Commitments in these sectors vary across EAC members and were to be implemented by the end of $2015 .{ }^{6}$ They are complemented by efforts to mutually recognize professional qualifications obtained by services suppliers in EAC states. As noted below, assessments of the extent to which commitments have been implemented suggest that progress has been slow.

There are several reasons to focus more on services in the context of regional integration efforts. One important reason is that the potential for trade between neighbouring or regional countries is significant and in many cases is greater than is realized, especially if informal trade is taken into account. The case study evidence noted above illustrates that intra-regional trade in many services is already occurring and has been dynamic. Creating conditions to move transactions out of the informal sphere and to facilitate cross-border exchange will not only support existing regional trade by lowering transaction costs but also allow trade to grow by encouraging firms to invest in higher value added services offerings and move along the extensive margin of trade.

In principle it should be easier to pursue services trade liberalization in a regionally cooperative setting. One reason for this is that the type of political economy dynamics that prevail for trade in goods may in fact be easier to overcome in the case of services because of their role as inputs into the production of firms in many different sectors as well as many, if not all, households. Thus, the inclusion of services on the agenda of regional integration initiatives may help to overcome resistance by domestic services interest groups by mobilizing a much larger number of stakeholders who stand to benefit from liberalization. More generally, international cooperation will often be a necessary condition for liberalization, as there needs to be mutual acceptance or recognition that regulatory norms and requirements in different countries are equivalent and/or satisfy minimum levels of quality. While the unilateral opening of services markets will often be feasible and beneficial - subject to compliance with prevailing domestic regulation and norms-this does not ensure access to partner country markets. Pursuing reforms in the context of a trade agreement can help to address political economy constraints on reforms by generating additional market access opportunities.

Various factors may explain the limited attention given to services in the context of regional integration efforts and the neglect of using trade agreements to pursue mutually beneficial reforms that would support greater trade in services. One is a lack of understanding of the importance of services for growth and productivity. While this has little to do with trade per se, it may be a factor that has led services trade to be neglected in trade agreements. Another likely reason for the relative neglect of services is that even when policymakers recognize the need to deal with the services policy agenda, there is uncertainty about how to do so in the context of trade agreements in a way that ensures that the domestic economy benefits (households and firms obtain greater access to

${ }^{6}$ Of the EAC members, Tanzania made the fewest commitments (59) and Rwanda the most (101) (World Bank and EAC 2016). 
better services; firms and workers will be able to utilize improved access to partner country markets; local service providers will not be swamped by foreign suppliers, etc.). This raises issues concerning the design of trade agreement commitments (e.g. sequencing; safeguarding provisions; adjustment mechanisms) and points to the need to ensure that regulatory institutions are adequate. A third possible factor centres on the political economy of trade agreements. As noted above, in principle the political economy of services reform should be less difficult to manage than the liberalization of trade in goods, as there are many more industries and groups in society who would benefit from better access to services. However, if this is not evident to these groups or, as is often the case (especially if the focus is mostly on goods), these groups are not consulted and have no voice in trade negotiations, these pro-reform dynamics may remain weak. One implication is that analysis is required to enhance understanding of the costs of status quo restrictive policies and the magnitude of the benefits (rents) that accrue to incumbent vested interests.

There are mechanisms that can be used in the context of regional integration efforts to identify both the need to address regulatory weaknesses and the priorities for joint reform by the parties to a trade agreement (i.e. liberalization). One template is to create knowledge platforms that bring together all groups with a stake in a given set of activities that jointly impact on the performance of a sector or value chain. Take the case of trade facilitation, a priority for many countries. This goes beyond matters of customs clearance and the operation of border crossings. Enhancing regional connectivity through trade facilitation and cooperation between customs and tax agencies to establish joint border posts and single windows needs to be complemented by cooperation to create efficient road corridors and effective transit regimes that allow trucks and people to move across borders and along transport routes, and cooperation in the setting and enforcement of health and safety standards and the certification/licensing of service providers. Knowledge platforms that bring together groups with a stake in a given sector, including industries that use a given service as an input, can help governments better understand where and why specific services reforms matter and areas where joint action by governments are needed (Hoekman and Mattoo 2013).

An example of what such an approach might generate is provided by Rwanda. The National Logistics and Distribution Services Strategy was developed to help mitigate Rwanda's logistical challenges. The strategy: (i) provided an enhanced role for Rwanda's logistics system; (ii) incorporated logistics services with value-added activities; (iii) strategically aligned logistics and distribution facilities to production centres; and (iv) led Rwanda to export logistics services. The strategy supported the development of projects and the mobilization of investment in logistics facilities to capitalize on longer value chains in the horticultural sector; regional logistics centres and land bridge improvements for the extended market's transit traffic; and air cargo market development to respond to overlapping market opportunities. This provides an illustration of how African countries can move up global value chains by leveraging regional opportunities (see Njinkeu and Hartmann 2015).

These considerations point to the need to think through (re-think) the design of and approach towards negotiation and implementation of international trade agreements to support welfareenhancing opening of services markets. The empirical literature on the design (content) and effects of services trade agreements suggests that most have not been very effective at opening services markets (Fink and Jansen 2009; Miroudot et al. 2010). Instead, unilateral reform appears to be the prime channel through which steps towards liberalization have been made. Djiofack-Zebaze and Keck (2009), for example, show that the effect of GATS commitments on the economic performance of the African telecommunications sector is rather weak in comparison with the positive effect of unilateral reforms. This points to the need to focus on national services trade policies. But that will not be enough, especially given the many countries in Africa and the many economies that are landlocked. As discussed in greater depth in Hoekman and Mattoo (2013), it is 
important that liberalization strategies/reform programmes go beyond questions of market access and include efforts to improve and strengthen regulatory regimes. This brings us back to the results of Beverelli et al. (2016) on the key role that economic governance quality plays in determining the magnitude of the net gains from services liberalization.

Regional reform programmes need to go beyond a focus on specific technical issues and pay attention to the political implications of the status quo-understanding who benefits and who loses, or who perceives that they will benefit or lose, from a policy or a proposed reform. This requires identifying the interests of the different stakeholders, how they are represented, how proreform coalitions can be built and strengthened, and how anti-reform interests can be accommodated. The organized (formal) private sector will play an effective and proactive role if and when it sees clear business opportunities. In East Africa, as Kenyan firms have increased their investment in other EAC partner states, they have increasingly lobbied their government to implement the EAC protocols of direct relevance to their sectors. ${ }^{7}$ This is particularly true of trucking companies interested in servicing the regional market, which have aggressively lobbied for more competition and improved efficiency, and have generally supported efforts to eliminate restrictions on foreign competition in the transport sector.

Other businesses that are more focused on the domestic market have acted in a different way. For example, the Kenya International Freight Forwarders and Warehousing Association and the Tanzania Freight Forwarders Association have seen regional integration in the transport sector as a threat to their business and as a result have been lobbying for less competition. Some members of these associations oppose allowing foreign clearing and forwarding agents to handle domestic cargo, while others see this as an opportunity for partnerships and mergers between the Tanzanian and/or Kenyan forwarders and their counterparts in landlocked partner countries. Business associations with memberships that span multiple countries may promote harmonization of business processes and better engagement with governments. In the case of the EAC, the East Africa Business Council, the Kenya Manufacturing Association, and the Kenya Private Sector Alliance, among others, play such a role. The transport sector associations, such as the Kenya Shippers Council and the Uganda Shippers Council, have made the Shippers Council of East Africa a powerful advocate for regional integration. Partly as a result, EAC member states are making some progress on regulatory harmonization in the transport sector, particularly with regard to axle load harmonization, through which all EAC member states use the same policy for axle loads.

An implication of such successful examples is that pragmatic acceptance of variable geometrybased approaches should be encouraged in pursuing regional cooperation to lower trade costs and integrate markets. Tanzania, and to some extent Burundi, has for a long time preferred slower integration of EAC members than Kenya, Rwanda, and Uganda. The heads of state of the latter three countries have supported a variable geometry-based timetable in such areas as infrastructure development, the single tourist visa, and enhanced labour mobility. This has facilitated the implementation of a Single Customs Territory along the Northern Corridor and has led to reduced border crossing times, the elimination of many weighbridges and police checkpoints on the roads, and growing compliance with weight restrictions. For example, a Regional Customs Transit Guarantee scheme covers transit goods from or to the ports and has eliminated multiple national transit guarantees. The regional scheme is accepted throughout the customs territory and this has supported greater intra-EAC trade and lowered costs for firms using the Northern Corridor. This

\footnotetext{
${ }^{7}$ What follows draws on Njinkeu and Hartmann (2015).
} 
in turn has had positive spillover effects on Tanzania and Burundi, as well as South Soudan and Eastern DRC. ${ }^{8}$

Flexibility in the design of cooperation and use of deliberation mechanisms such as knowledge platforms needs to be complemented by information on prevailing policies and objective analysis of their economic effects. Given agreement to commit to specific reforms, it is also important to monitor implementation so as to inform stakeholders and policymakers on progress and to identify areas where progress is not being made and assess why. The EAC has developed a mechanism (supported by the donor community through TradeMark East Africa and the World Bank) to generate information through a 'scorecard' that tracks compliance in implementing EAC services liberalization commitments. The latest scorecard (World Bank and EAC 2016) indicates that the two large EAC counties are lagging behind other EAC members on road transport liberalization and that most instances of noncompliance-across all EAC members-are for professional services (some three-quarters of all nonconforming measures). The scorecard process makes transparent where progress has been achieved and where attention needs to be focused. Between 2014 and 2016, only 6 out of 63 nonconforming services restricting measures were removed and two new ones were put in place. The fact that most nonconforming measures in the EAC pertain to professional services and that there are fewer nonconforming measures for transport may be explained in part by the types of regional mechanism mentioned previously, which focus on transport and logistics.

\section{$7 \quad$ Concluding remarks}

Services play a critical role in economic growth and development. Trade in services is a key channel through which countries can exploit their comparative advantage. Sectors such as tourism and business process outsourcing can generate substantial employment and foreign exchange earnings. More generally, however, it is important to recognize that services activities affect economic development through a variety of indirect channels. Opening trade and investment in services to foreign competition is a source of new knowledge and new products that can have a major impact on the productivity, and thus competitiveness, of many firms in the economy. Services account for a substantial share of the total costs of production of many firms in many sectors. Reducing these costs and increasing the quality of available services is therefore a mechanism through which to increase economy-wide performance.

That said, the economic research literature also makes clear that services liberalization is not a panacea. The quality of prevailing economic governance, implementing institutions, and regulatory regimes will determine how much a country stands to benefit from opening services markets to foreign competition. This strengthens the case for a concerted and consistent focus on improving economic governance as a necessary condition for sustained growth. The more trade agreements are designed to promote that goal, the more valuable they will be from a development perspective. The question is how to do so, a subject that has not attracted the attention it deserves. Mechanisms of the type that have been put in place in the EAC context are steps in the right direction, but a precondition is that governments are willing to use regional integration processes to liberalize services trade and to identify where this needs to be complemented by regulatory reform and regional regulatory cooperation.

\footnotetext{
${ }^{8}$ See Kunaka et al. (2016) for a detailed discussion.
} 


\section{References}

ACET (African Center for Economic Transformation) (2014). 'African Transformation Report 2014: Growth with Depth'. Accra: ACET.

Arnold, J., A. Mattoo, and G. Narciso (2008). 'Services Inputs and Firm Productivity in SubSaharan Africa: Evidence from Firm Level Data'. Journal of African Economies, 17(4): 578-99.

Arnold, J., B. Javorcik, and A. Mattoo (2011). 'Does Services Liberalization Benefit Manufacturing Firms? Evidence from the Czech Republic'. Journal of International Economics, 85(1): 136-46.

Arvis, J.F., Y. Duval, B. Shepherd, and C. Utoktham (2015). 'Trade Costs in the Developing World: 1995-2010'. World Trade Review, doi: http://dx.doi.org/10.1017/S147474561500052X (accessed 2 February 2017).

Balchin, N., B. Hoekman, H. Martin, M. Mendez-Parra, P. Papadavid, and D.W. te Velde (2016). Trade in Services and Economic Transformation. London: ODI.

Balistreri, E., T. Rutherford, and D. Tarr (2009). 'Modeling Services Liberalization: The Case of Kenya'. Economic Modelling, 26(3): 668-79.

Barone, G., and F. Cingano (2011). 'Service Regulation and Growth: Evidence from OECD Countries'. Economic Journal, 121(555): 931-57.

Bas, M. (2014). 'Does Services Liberalization Affect Manufacturing Firms' Export Performance? Evidence from India'. J. Comp. Econ., 42: 569-89.

Baumol, W. (2012). The Cost Disease. New Haven: Yale University Press.

Berlingieri, G. (2014). 'Outsourcing and the Rise in Services’. CEP Discussion Paper 1199.

Beverelli, C., M. Fiorini, and B. Hoekman (2016). 'Services Trade Restrictiveness and Manufacturing Productivity: The Role of Institutions'. Journal of International Economics. Available at: http://dx.doi.org/10.1016/j.jinteco.2016.11.001 (accessed 2 February 2017).

Borchert, I., B. Gootiiz, and A. Mattoo (2014). 'Policy Barriers to International Trade in Services: Evidence from a New Database'. World Bank Economic Review, 28(1): 162-88.

Borchert, I., B. Gootiiz, A. Grover, and A. Mattoo (2015). 'Services Trade Protection and Economic Isolation.' The World Economy, doi: http://dx.doi.org/10.1111/twec.12327 (accessed 2 February 2017).

Bourlès, R., G. Cette, J. Lopez, J. Mairesse, and G. Nicoletti (2013). 'Do Product Market Regulations in Upstream Sectors Curb Productivity Growth? Panel Data Evidence for OECD Countries'. Rev. Econ. Stat., 95: 1750-68.

Breinlich, H., and C. Criscuolo (2011). 'International Trade in Services: A Portrait of Importers and Exporters'. J. Int. Econ., 84: 188-206.

Cali, M., K. Ellis, and D. te Velde (2008). The Contribution of Services to Development and the Role of Trade Liberalisation and Regulation. London: ODI.

Cattaneo, O., M. Engman, S. Saez, and R. Stern (eds) (2010). International Trade in Services: New Trends and Opportunities for Developing Countries. Washington, DC: World Bank.

Dihel, N., and A. Goswami (eds) (2016). From Hair Stylists and Teachers to Accountants and Doctors The Unexplored Potential of Trade in Services in Africa. Washington, DC: World Bank.

Dihel, N., A. Fernandes, R. Gicho, J. Kashangaki, and N. Strychcz (2012). 'Becoming a Global Exporter of Business Services? The Case of Kenya'. In A. Goswami, A. Mattoo, and S. Sáez 
(eds), Exporting Services: A Developing Country Perspective. Washington, DC: World Bank, pp. 23769.

Djiofack-Zebaze, C., and A. Keck (2009). 'Telecommunications Services in Africa: The Impact of WTO Commitments and Unilateral Reform on Sector Performance and Economic Growth'. World Dev., 37: 919-40.

Duggan, V., S. Rahardja, and G. Varela (2013). 'Service Sector Reform and Manufacturing Productivity: Evidence from Indonesia'. World Bank Policy Research Working Paper 6349.

Eichengreen, B., and P. Gupta (2009). 'The Two Waves of Service Sector Growth.' NBER Working Paper 14968.

Eschenbach, F., and B. Hoekman (2006). 'Services Policy Reform and Economic Growth in Transition Economies'. Review of World Economics, 142(4): 746-64.

Fink, C., and M. Jansen (2009). 'Services Provisions in Regional Trade Agreements: Stumbling or Building Blocks for Multilateral Liberalization?’ In R. Baldwin and P. Low (eds), Multilateralizing Regionalism. Cambridge University Press.

Francois, J., and B. Hoekman (2010). 'Services Trade and Policy'. Journal of Economic Literature, 48(3): 642-92.

Herrendorf, B., R. Rogerson, and A. Valentinyi (2013). 'Growth and Structural Transformation'. NBER Working Paper 18996.

Hoekman, B., and A. Mattoo (2013). 'Liberalizing Trade in Services: Lessons from Regional and WTO Negotiations'. International Negotiation, 18(1): 131-51.

Hoekman, B., and B. Shepherd (2015a). 'Who Profits from Trade Facilitation Initiatives? Implications for African Countries'. Journal of African Trade, 2(1-2): 51-70.

Hoekman, B., and B. Shepherd (2015b). 'Services Productivity, Trade Policy and Manufacturing Exports'. The World Economy, doi: dx.doi.org/10.1111/twec.12333 (accessed 2 February 2017).

Jensen, J., T. Rutherford, and D. Tarr (2010). 'Modeling Services Liberalization: The Case of Tanzania'. Journal of Economic Integration, 25(4): 644-75.

Karingi, S., and W. Davis (2016). 'Towards a Transformative African Integration Process: Rethinking the Conventional Approaches'. UNECA, mimeo.

Konan, D., and K. Maskus (2006). 'Quantifying the Impact of Services Liberalization in a Developing Country'. J. Dev. Econ., 81: 142-62.

Kravis, I.B., A.W. Heston, and R. Summers (1983). 'The Share of Services in Economic Growth'. In F. Gerard Adams and Bert G. Hickman (eds), Global Econometrics: Essays in Honor of Lawrence R. Klein. Cambridge, Mass.: MIT Press, pp. 188-218.

Kunaka, C., G. Raballand, and M. Fitzmaurice (2016). 'How Trucking Services have Improved and May Contribute to Economic Development: The Case of East Africa.' UNU-WIDER Working Paper 2016/152.

Low, P. (2013). 'The Role of Services'. In D. Elms and P. Low (eds), Global V alue Chains in a Changing World. World Trade Organization.

Mattoo, A., and L. Payton (eds) (2007). Services Trade and Development: The Experience of Zambia. Washington, DC: Palgrave and World Bank.

Mattoo, A., R. Rathindran, and A. Subramanian (2006). 'Measuring Services Trade Liberalization and Its Impact on Economic Growth: An Illustration'. J. Econ. Integr., 21: 64-98. 
McMillan, M., and D. Rodrik (2011). 'Globalization, Structural Change and Productivity Growth'. NBER Working Paper 17143.

Miroudot, S., and B. Shepherd (2016). 'Trade Costs and Global Value Chains in Services'. In M. Roy and P. Sauvé (eds), Research Handbook on Trade in Services. Edward Elgar.

Miroudot, S., J. Sauvage, and M. Sudreau (2010). 'Multilateralising Regionalism: How Preferential Are Services Commitments in Regional Trade Agreements?' OECD Trade Policy Working Paper 106.

Miroudot, S., J. Sauvage, and B. Shepherd (2012). 'Trade Costs and Productivity in Services Sectors'. Econ. Lett., 114: 36-38.

Newman, C., J. Page, J. Rand, A. Abebe, M. Soderbom, and F. Tarp (2016). Manufacturing Transformation: Comparative Studies of Industrial Development in Africa and Emerging Asia. Oxford: Oxford University Press.

Njinkeu, D., and O. Hartmann (2015). 'Unlocking Trade for Low-income Countries: Report of the Trade Facilitation Facility, 2009-2015'. Washington, DC: The World Bank.

Nordås, H.K. (2011). 'Opening the Markets for Business Services: Industrial Perspective for Developing Countries'. J. Econ. Integr., 26: 306-28.

Rodrik, D. (2014). 'An African Growth Miracle?’ NBER Working Paper 20188.

Saez, S., D. Taglioni, E. van der Marel, C. Hollweg, and V. Zavacka (2015). Valuing Services in Trade: A Toolkit for Competitiveness Diagnostics. Washington, DC: World Bank.

Schettkat, R., and L. Yocarini (2006). 'The Shift to Services Employment: A Review of the Literature'. Structural Change and Economic Dynamics, 17(2): 127-47.

Storeygard, A. (2016). 'Farther on down the Road: Transport Costs, Trade and Urban Growth in Sub-Saharan Africa'. Review of Economic Studies, 83: 1263-95.

Van der Marel, E. (2012). 'Trade in Services and TFP: The Role of Regulation'. World Econ., 35: 1530-58.

Wagner, J. (2012). 'International Trade and Firm Performance: A Survey of Empirical Studies Since 2006'. Rev. World Econ., 148: 235-67.

World Bank (2010). International Trade in Services, Trade and Development. World Bank Group.

World Bank (2014). Connecting to Compete, 2014: Trade Logistics in the Global Economy. Washington, DC: World Bank.

World Bank and EAC Secretariat (2016). 'EAC Common Market Scorecard: Tracking EAC Compliance in Movement of Capital, Services and Goods'. Arusha: EAC Secretariat.

Young, A. (2014). 'Structural Transformation, the Mismeasurement of Productivity Growth and the Cost Disease of Services'. American Economic Review, 104(11): 3635-67. 